\title{
Robert Goczał
}

Papieski Wydział Teologiczny we Wrocławiu

\section{TEORIA POZNANIA INTELEKTUALNEGO (UJĘCIE FRANCISZKA SUÁREZA SJ) ${ }^{1}$}

Koncepcja poznania, a w szczególności teoria „intencji poznawczych”, którą Suárez († 1617) zastosował w metafizyce, ujawnia wiele istotnych szczegółów poznania intelektualnego i znajduje dokładne potwierdzenie już we wcześniejszych koncepcjach, m.in. u św. Tomasza z Akwinu († 1274) w koncepcji „bytu zmniejszonego” (ens diminutum lub ens incompletum), w logice XIII wieku u Jana Dunsa Szkota († 1308), a także później u Wilhelma Ockhama († ok. 1350) i Pawła z Wenecji († 14.28) ${ }^{2}$.

Mimo niezaprzeczalnie średniowiecznej chronologii pierwszeństwa teoria „intencji poznawczych” („pierwszej” i „drugiej” intencji) nie zakłada u Suáreza wpływu innych autorów, zwłaszcza że w jego filozofii

1 Artykuł jest skróconą i merytorycznie uzupełnioną wersją drugiego rozdziału publikacji: R. Goczał, Onto-teo-logia. Status bytu realnego i myślnego w metafizyce Francisco Suareza, Warszawa 2011.

2 Por. S. Swieżawski, Les intentions premières et les intentions secondaires chez Jean Duns Scotus, „Archives d'Histoire Doctrinale et Littéraire du Moyen Âge” (1934) 9, s. 205-26o; W. Ockham, Suma logiczna, przeł. T. Włodarczyk, Warszawa 1971, ks. I, rozdz. 2, s. 55-58. Zob. także Sancti Thomae Aquinatis, Scriptum super Sententiis magistri Petri Lombardi, t. 1, ed. P. Mandonnet, Parisiis: P. Lethielleux 1929, ks. I, dist. II, q. 1, art. 1, c. 3; Paulus Venetus, Logica Parva, First Critical Edition from The Manuscripts with Introduction and Commentary, transl. and ed. by A. R. Perreiah, Leiden-BostonKöln 2002, rozdz. 2 (On Supposition), sek. 2 (Material and Personal Supposition); albo wydanie Münich 1984, s. 144-147. Na temat „drugich intencji” w średniowieczu zob. A. D. Conti, Second Intentions in the Late Middle Ages, w: Medieval Analysis in Language and Cognition, eds. S. Ebbesen, R. Friedmann, Copenhagen 1999, s. 453-470. 
teoria ta zdaje się najlepiej odpowiadać zastosowaniu bardziej na gruncie metafizyki aniżeli logiki. De facto pojęcie „pierwszej” i „drugiej” intencji poznawczej stało się autentycznym wyznacznikiem metody definiowania poznania intelektualnego w scholastyce średniowiecznej i odrodzeniowej. W znakomitej większości pism Suáreza, szczególnie w Disputationes metaphysicae, napotykamy elementy teoriopoznawcze, które w istotny sposób są powiązane z jego esencjalizmem i logiką, aczkolwiek były już stosowane w średniowieczu. W każdym razie hipoteza o stosowaniu teorii „intencji poznawczych”, która w metafizyce Suáreza stanowi stopień pośredni w metafizyce poznania, dodatkowo wyznacza metodę interpretowania metafizycznej relacji, jaka zachodzi w aktualnie odbywającym się poznaniu między intelektem czynnym a możnościowym. Co więcej, tego rodzaju powiązanie u Suáreza bardziej precyzuje w jego ujęciu koncepcję dematerializacji formy poznawczej (species). Nie sposób jednak przeoczyć faktu, że wykorzystanie logicznej teorii „intencji poznawczych” wraz z koncepcją uprzedmiotowienia bytu na gruncie metafizyki oddala go od tradycji tomistycznej. W niniejszym artykule staram się zrekonstruować teorię „intencji poznawczych” u Suáreza i na tym tle wykazać zasadniczą różnicę w stosunku do tradycji arystotelesowsko-tomistycznej, zwłaszcza w odniesieniu do pojęcia „bytu przedmiotowego” (ens obiectivum), które dla Suáreza stanowi fundamentalną ideę poznania intelektualnego w procesie dematerializacji form między intelektem czynnym i możnościowym.

W kontekście teorii poznania u Suáreza jest doprawdy znamienne, że budowę systemów filozoficznych - zwłaszcza po René Descarcie († 1650) - zaczęto opierać na analizie struktur poznania, myślenia, nie zaś bytu, sprowadzając przedmiot poznania do treści podmiotowego aktu poznawczego (np. kantowskie formy zmysłowości). Ponadto zmiana perspektywy ontologicznej w obrębie metafizyki, jaką obserwujemy już wcześniej u Suáreza - z orientacji egzystencjalnej (tomistycznej) na tendencję zmierzającą w kierunku esencjalizacji bytu, przyznającej priorytet „istocie” względem „istnienia” - jest sugestywnym znakiem końca scholastyki tradycyjnej. Wyeksponowanie tego ostatniego rozróżnienia podkreśla zasadniczą odmienność metafizyki tomistycznej 
w stosunku do wszystkich opozycyjnych koncepcji. Niemniej jednak tendencja ta zaznaczyła się w wiekach wcześniejszych, przede wszystkim dostrzega się jej obecność już w stanowisku Awicenny († 1037), Dunsa Szkota czy nominalistów Roscelina z Compiègne († ok. 1125) i Wilhelma Ockhama ${ }^{3}$. Ten charakterystyczny schemat odstąpienia od klasycznego wzorca uprawiania metafizyki na rzecz koncepcji esencjalistycznej (noetyczno-logikalnej), a wręcz transcendentalnej w sensie nowożytnym, znajduje istotne odzwierciedlenie w metafizyce prezentowanej przez Suáreza, Piotra da Fonsekę († 1599), Dominika de Soto († 1560), a nawet dominikanów Johannesa von Sterngassena († 1327) i Hervaeusa Natalisa († 1332), autora traktatu o pierwszych zasadach poznania (De cognitione primi principia) i „drugich intencjach” (Tractatus de secundis intentionibus) ${ }^{4}$.

Okres scholastyki odrodzeniowej XVI i XVII wieku, w której tworzył Suárez, jest zatem okresem szczególnie zaznaczającego się wzrostu zainteresowań nową metodologią, problematyką teoriopoznawczą, w obrębie której dominuje przeświadczenie o opracowaniu nowych metod poznawczych ${ }^{5}$. Pojmowanie filozofii odznacza się wyraźnym zain-

${ }^{3}$ M. Grabmann, Die Disputationes Metaphysicae des Franz Suárez in ihrer methodischen Eigenart und Fortwirkung, w: Mittekakterkuches Geustesleben. Abhandlungen zur Geschichte der Scholastik und Mystik, München 1926, s. 517-524.

${ }^{4}$ M. Grabmann, Die Disputationes Metaphysicae..., dz. cyt. Zagadnienie esencjalizmu Grabmann sytuuje na tle sporu o kategorię różnicy między „istotą” a „istnieniem" (distinctio realis, distinctio modalis czy distinctio rationis). Jednocześnie ukazuje on kontekst historyczno-analityczny tego fundamentalnego dla metafizyki Suáreza problemu. Transcendentalną wykładnię bytu u Suáreza w sensie nowożytnym, ujętą na tle tradycji, przedstawia również Rolf Darge. Zob. R. Darge, Suárez' transzendentale Seinsauslegung und die Metaphysiktradition, Leiden-Boston 2004.

${ }^{5}$ Kształtowanie renesansowej teorii poznania wokół metody omawia Walter J. Ong SJ w swojej liczącej ponad 1700 stron rozprawie doktorskiej, wydanej w wersji skróconej przez Harvard University Press w 1958 roku pod tytułem Ramus, Method and the Decay of Dialogue: From the Art of Discourse to the Art of Reason. Praca została poświęcona myśli XVI-wiecznego francuskiego filozofa i logika Pierre'a de la Ramee (Ramus), wykładowcy w College de France, który wystąpił z otwartą krytyką dialektyki i retoryki Arystotelesa oraz Kwintyliana. Był autorem ponad 61 dzieł spisanych po 
teresowaniem tematyką metalogiczną (systemy dedukcyjne, semantyka logiczna, logiczne teorie języka) oraz dominacją tendencji analityczno-krytycznych i logicznych (via moderna) w stosunku do tradycyjnego uprawiania filozofii (via antiqua). Tradycyjna logika „starej szkoły” to przede wszystkim teoria poznania, w której mieściły się jeszcze rozważania z zakresu metafizyki, metodologii, semiotyki (teoria oznaczania), gramatyki i logiki w węższym znaczeniu (Piotr Hiszpan, † 1277, terminizm XIV-wieczny) ${ }^{6}$. Dzięki XIV-wiecznym traktatom logicznym - zwłaszcza nominalistów Duranda z Saint Pourçain († 1334), Ockhama i Piotra Aureoli († 1322), który przed Ockhamem twierdził, że pojęcia intelektu są fikcjami - które zawierały ściśle ustalone reguły dyskusji, charakteryzujące scholastyczny system nauczania, stanowiły już wcześniej inspirację dla licznych myślicieli środowisk intelektualnych uniwersytetów oksfordzkiego i paryskiego. Wiązało się to ze stopniowym redukowaniem w refleksji filozoficznej zagadnień metafizyki arystotelesowsko-tomistycznej. Ta szczególnie wyraźna tendencja poszukiwania nowej metodologii - dostrzegana głównie wśród zwolenników filozofii ockhamistycznej w osobach Franciszka z Meyronnes († ok. 1328), Franciszka z Marchii (Francisco de Esculo) († ok. 1344) oraz Wilhelma Alnwicka († 1322) - została szybko rozpropagowana w następnych dwóch stule-

łacinie, które obejmowały szeroki wachlarz problemów, zarówno poświęconych dialektyce, metafizyce, jak i teologii, matematyce czy fizyce. Jego prace zostały przełożone na ponad 40 języków. W okresie protestanckiej reformy z 1562 roku przebywał w Niemczech i Szwajcarii. Został zamordowany po powrocie do Francji w trzeci dzień Masakry św. Bartłomieja. Por. Encyclopedia of Philosophy, ed. P. Edwards, t. 7, New York 1967, s. 56-57, 66. Zob. również W. J. Ong SJ, Ramus, Method and the Decay of Dialogue: From the Art of Discourse to the Art of Reason, Chicago 2005, zwł. s. 121-123.

${ }^{6} \mathrm{Na}$ temat logiki tradycyjnej i scholastycznej zob. H. Scholz, Zarys historii logiki, przeł. M. Kurecka-Wirpszowa, Warszawa 1965; A. S. Moreno, Logica Medieval, „Sapientia” (1961) 16, s. 246-265; A. E. Moody, The Medieval Contribution to Logic, „Studium General” (1966) 19, s. 443-452; J. Pinborg, Logic und Semantik im Mittelalter. Ein Überblick, Stuttgart 1972; N. Kretzman, Semantics, History of, w: The Encyclopedia of Philosophy, ed. P. Edwards, New York 1967; E. J. Ashworth, The Tradition of Mediaeval Logic and Speculative Grammar, Toronto 1978. 
ciach $^{7}$. W efekcie czego późnośredniowieczny terminizm przyczynił się do wzrostu zainteresowań problematyką logiczną i szybkiego rozwoju konceptualizmu scholastyki odrodzeniowej.

Już przed Suárezem Ockham wprowadził podział między esse subiectivum i esse obiectivum, wykorzystując przy tym teorię „intencji poznawczych" na gruncie metafizyki poznania. ${ }^{8}$ W tej sytuacji nie trudno zauważyć, że problematyka określania czynników apriorycznych w poznaniu u Suáreza zasadzała się na przeformułowaniu tradycyjnej koncepcji poznania i wprowadzeniu do metafizyki logikalnej struktury "intencji poznawczych” oraz pojęcia „bytu przedmiotowego”. Teoria "pierwszych" i "drugich intencji” intelektu (primae et secundae intentionis), która stanowiła w średniowieczu podstawę rozumowania w obrębie logiki tradycyjnej, u Suáreza zostaje więc przeniesiona na grunt metafizyki, gdzie ma ścisłe zastosowanie w poznaniu ontologicznym?

7 Wszystko to ze zdziwienia. Antologia tekstów filozoficznych XIV wieku, oprac. E. Jung-Palczewska, Warszawa 200o, s. xxxvii.

8 "Intellectus noster primo intelligi intuitive aliquid singulare realiter existens, quo intellecto potest idem intellectus fingere aliquid consimile prius intellecto, sed illud fictum non poterit habere esse subjectivum, sed tantum esse objectivum... et ideo illud sic fictum est tantum tale, quale fuit prius intellectum in esse objectivo et non est in esse subjectivo, sed erit quasi imago simillima rei prius intellectae in esse objectivo..." (G. de Ockham, Scriptum in libros Sententiarum seu Ordinatio, w: G. de Ockham, Opera philosophica et theologica, cura Instituti Franciscani, Universitatis S. Bonaventurae, Opera theologica, t. 3, ed. Ph. Boehner OFM, G. Gál OFM, S. Brown, New York 1977, I, dist. 13, q. 1); „Universale non est aliquid reale habens esse subjectivum nec in anima nec extra animam, sed tantum habet esse objectivum in anima et est quoddam fictum habens esse tale in esse objectivo, quale habet res extra in esse subjectivo" (G. de Ockham, Scriptum in libros Sententiarum seu Ordinatio, dz. cyt., I, dist. 2, q. 8).

9 Zob. F. Suárez, Disputationes metaphysicae, disp. II, sek. 1-2, w: Opera omnia. Editio nova, a C. Berton, t. 25, Parisiis 1866 [dalej: Disputationes metaphysicae]. Zob. również opracowania M. Forlivesi, La distinction entre concept formel et concept objectif: Suárez, Pasqualigo, Mastri, trad. di O. Boulnois, „Les Études Philosophiques” (2002) 1 , s. 3-30; J. Hellín, El concepto formal en Suárez, „Pensamiento” (1962) 18, s. 407-432; N. J. Wells, „Esse cognitum” and Suárez Revisited, „American Catholic Philosophical Quarterly" (1993) 67, s. 339-348. Zob. także A. Maryniarczyk SDB, Transcendentalia w perspektywie historycznej. Od arché do antytranscendentaliów, w: św. Tomasz z Akwi- 
1. DYSTYNKCJA MIĘDZY „PIERWSZĄ” A „DRUGĄ INTENCJĄ INTELEKTU"

W noetyce tomistycznej pojęcie „intelektu” jest definiowane w oparciu o analizę procesów poznawczych aktów duszy, rozpatrywanych w świetle ich ontycznych uwarunkowań. Otóż przeprowadzona przez Suáreza analiza dystynkcji między aktem „pierwszej” a „drugiej intencji” pogłębia zarazem rozumienie „intelektu” w sensie tomistycznym od strony procesów poznawczych poprzez wyznaczenie realnego bądź czysto myślnego charakteru przedmiotu najwyższej instancji poznawczej duszy, jaką jest intelekt. Natomiast działania zmysłów, woli oraz uczuć traktuje on jako przyporządkowane i w istotny sposób zależne od aktywności poznawczej intelektu. W świetle tej dystynkcji intelekt, jako wyższa władza poznawcza duszy, ma do czynienia w ujęciu poznawczym z przedmiotem „drugich intencji”, przedmiotem niejako logikalno-pojęciowej struktury intelektu, któremu można wówczas przypisać aktywność czysto poznawczą. Ontologiczna charakterystyka „bytu przedmiotowego”, jaką przeprowadza Suárez, wykazuje, że w tym ujęciu przedmiotem metafizyki stają się immanentne konstrukcje czystego intelektu, których fundament bezpośrednio nie mieści się w bycie realnym (ens reale). Przedmiot „drugich intencji”, a więc „byt przedmiotowy”, nie zakłada bezpośrednio rzeczywistości realnej. W tym wypadku akt poznania jest nakierowany na „pierwszą”, formalną intencję intelektu, jaką jest pojęcie ogólne wyabstrahowane z rzeczy (powszechnik). Jedynie „pojęcie formalne” jest skorelowane z „bytem realnym”.

Ponadto należy zwrócić szczególną uwagę, iż pojęcie „intencji” w ujęciu Suáreza nie wyraża „aktu woli” (actus voluntatis) zorientowanego na realizację końcową przedsiębranego celu czy też „aktu wyboru” oznaczającego urzeczywistnienie tego celu, ale w tym iście scholastycznym rozumieniu oznacza pojęciowy akt intelektu (actus intellectus), który jest nakierowaniem poznawczym na rzecz obecną w poznaniu. Akt intelek-

nu, De veritate. O prawdzie, przekł. A. Białek, tekst poprawili M. A. Krąpiec OP, A. Maryniarczyk SDB, Lublin 1999, s. 130-133. 
tu „drugiej intencji” jest jednocześnie nastawieniem i ujęciem poznawczym rzeczy obecnej w intelekcie, a raczej jej „metauogólnieniem” lub „metaformalizacją”. Intencja ta nazywana jest „nakierowaniem poznawczym intelektu", ponieważ kieruje się ku rzeczy poznawczej, ku innemu przedmiotowi, który pojawia się w czystej abstrakcji. Jest jakby meta-przedmiotowym poznaniem rzeczy od strony jej aspektu poznawczego, a więc jest meta-przedmiotową refleksją intelektu nad przedmiotem jako przedmiotem poznawczym.

W związku z powyższym Suárez „pojęcie” nazywa raz formalnym, innym razem przedmiotowym, podobnie też istnieje „intencja formalna” (intentio formalis), jak i "intencja przedmiotowa” (intentio obiectiva) ${ }^{10}$. „Relacja myślna” (relatio rationis), która jest nakierowaniem intelektu na rzecz poznawczą (attribuitur rei cognitae), jest określana przez Suáreza jako „intencja przedmiotowa”, z kolei akt ujęcia pojęciowego, poprzez który intencja ta powstaje, nazwany jest „intencją formalną”11. Na przykład, w wypadku rozważanego „zwierzęcia” (Suárez podaje także przykład działania łaski w człowieku) - rodzaj najbliższy i nadrzędna zakresowo klasa przedmiotów dla gatunku ludzkiego - „uniwersalność" lub „ogólność” pojęcia osiągane po stronie ujętej w intelekcie rzeczy nazywane są „przedmiotowymi” (obiectiva). Natomiast samo pojęcie ogólne „zwierzę”, pojęcie wyabstrahowane, nazywane jest „intencją formalną"12. Stąd też „intencja formalna” jest relacją odrębnego typu

${ }^{10}$ Disputationes metaphysicae, disp. VIII, sek. 1, art. 1.

11 „1. Conceptus formalis et obiectivus quid sint, et in quo differant. - Supponenda imprimis est vulgaris distinctio conceptus formalis et obiectivi; conceptus formalis dicitur actus ipse, seu (quod idem est) verbum quo intellectus rem aliquam seu communem rationem concipit; qui dicitur conceptus, quia est veluti proles mentis; formalis autem appellatur, vel quia est ultima forma mentis, vel quia formaliter repraesentat menti rem cognitam, vel quia revera est intrinsecus et formalis terminus conceptionis mentalis, in quo differt a conceptu obiectivo, ut ita dicam. Conceptus obiectivus dicitur res illa, vel ratio, quae proprie et immediate per conceptum formalem cognoscitur seu repraesentatur" (Disputationes metaphysicae, disp. II, sek. 1, art. 1).

12 „Conceptus obiectivus dicitur res illa, vel ratio, quae proprie et immediate per conceptum formalem cognoscitur seu repraesentatur; ut, verbi gratia, cum hominem conci- 
niż „intencja przedmiotowa”. Przy czym aspekt formalny „drugiej intencji”, który zostaje uchwycony od strony rzeczy poznawczej, jest znowu czymś innym. Formalność (formalitas) „drugiej intencji”, która jest jakby zawartością i bytem rzeczy wyabstrahowanej ${ }^{13}$, jest zawsze czymś myślnym, jako że zawsze jest bytem czegoś, co wynika tylko z poznania. Z kolei „intencja formalna” jest aktem intelektu, której byt sam w sobie nie czerpie racji istnienia i nie zależy wyłącznie od poznania intelektualnego, albowiem po stronie „intencji formalnej” - zwanej pierwszą jest zawsze coś realnego.

Metaformalność, która mieści się w „drugiej intencji”, jest właśnie „drugą intencją”. Owa „druga intencja” różni się od „pierwszej”, ponieważ jest drugim poziomem lub warunkiem istnienia przedmiotu jako przedmiotu poznawczego w ujęciu intelektualnym. Przedmiot w poznaniu intelektualnym może być rozważany od strony dwóch aspektów: 1) zostaje ujęty tak, jak istnieje sam w sobie (secundum quod est in se); wówczas poznanie odnosi się do jego istnienia (ad existentiam) lub dotyczy struktury definicyjnej bytu realnego, istotnościowej (ad quidditatem $)^{14}$, albo też 2) przedmiot zostaje ujęty tak, jak istnieje on $\mathrm{w}$ ujęciu przedmiotowo-poznawczym (in apprehensione obiective) ${ }^{15}$. Ten przyporządkowany w poznaniu status istnienia przedmiotu nazywany jest „drugim” poziomem istnienia w odróżnieniu od „pierwszego”, w którym przedmiot jest poznawany względem istnienia (secundum esse).

pimus, ille actus, quem in mente efficimus ad concipiendum hominem, vocatur conceptus formalis; homo autem cognitus et repraesentatus illo actu dicitur conceptus obiectivus, conceptus quidem per denominationem extrinsecam a conceptu formali, per quem obiectum eius concipi dicitur, et ideo recte dicitur obiectivus..." (Disputationes metaphysicae, disp. II, sek. 1, art. 1).

${ }^{13}$ Disputationes metaphysicae, disp. LIV, sek. 2, art. 1.

${ }^{14}$ Disputationes metaphysicae, disp. VI, sek. 7, art. 2.

${ }^{15}$ Disputationes metaphysicae, disp. LIV, sek. 2, art. 13; „Alio ergo modo dicitur aliquid esse in ratione per modum obiecti, nam quia cognitio fit per quamdam assimilationem et quasi attractionem rei cognitae ad cognoscentem, dicitur res cognita esse in cognoscente, non solum inhaesive per suam imaginem, sed etiam obiective secundum seipsam" (Disputationes metaphysicae, disp. LIV, sek. 1, art. 5). 
Zatem wszystkie stany czy właściwości intelektu, formalności, których poznawanie odnosi się pośrednio lub bezpośrednio do rzeczy istniejących „samych przez się” (per se), nazywane są przez Suáreza „pierwszymi intencjami", natomiast te, które odnoszą się do rzeczy istniejących tylko „w" i „dzięki” poznaniu, nazywa on „drugimi intencjami”.

Jednakże akt ujęcia przedmiotowego „drugiej intencji” nie jest abstrakcją formalną. „Druga intencja” zawsze zakłada swój fundament bytowy wyłącznie w bycie poznawczym (esse cognitum). „Druga intencja” wprowadza "zewnętrzną denominację" intelektu (denominatio extrinseca), a więc myślny opis przedmiotu formalnego, w rzecz poznawczą i wyabstrahowaną, w istocie jednak "druga intencja" intelektu nie jest samą tą "zewnętrzną denominacją" ani też żadną formą realną ${ }^{16}$. Gdyby bowiem "druga intencja” intelektu była formą realną, byłaby zawarta realnie $\mathrm{w}$ indywiduach, a nie $\mathrm{w}$ tym, co jest wyabstrahowanym przedmiotem tych indywiduów i co jest zarazem emanacją czystego intelektu. Jakkolwiek ten akt intelektu, który dokonuje abstrakcji, wydobywając przedmiot ogólny z indywiduów, jest aktem realnym intelektu, niezależnym od bytu ujętego poznawczo. Nie jest on „drugą intencją przedmiotową", ale jest zawsze „intencją formalną", z której dopiero w następstwie refleksji intelektu nad własnym poznaniem powstaje byt przedmiotowy "drugiej intencji” ${ }^{\prime 17}$.

${ }^{16}$ „....homo autem cognitus et repraesentatus illo actu dicitur conceptus obiectivus, conceptus quidem per denominationem extrinsecam a conceptu formali, per quem obiectum eius concipi dicitur" (Disputationes metaphysicae, disp. II: Utrum ens habeat unum cnceptum seu rationem formalem obiectivam, sek. 1, art. 1). Na temat teorii „zewnętrznej denominacji” u Suáreza zob. Disputationes metaphysicae, disp. XXXIX, art. 6-7, 37; disp. XVI, sek. 1, art. 24; disp. II, sek. 1, art. 1; disp. XXIII, sek. 8, art. 8; disp. XXV, sek. 1, art. 31-32; disp. XLVII, sek. 14, art. 5. Zob. również J. P. Doyle, Prolegomena to a Study of Extrinsic Denomination in the work of Francis Suárez S. J., „Vivarium” (1984) 22, s. 121-16o. Zob. także Ioannis a Sancto Thoma, Cursus Philosophicus Thomisticus, t. 1, Ars Logica, Parisiis 1883, q. II (De Ente Rationis Logico, Quod Est Secunda Intentio), 285b33-286a11.

17 ,....proprie tamen illa operatio est reflexa, et (ut ita dicam) est per se secunda, quae cadit in aliam cognitionem, vel in obiectum prout denominatum a priori cognitione, et 
Intelekt jest refleksyjny w stosunku do swoich aktów, może zatem ująć w poznaniu refleksyjnym sam akt „drugiej intencji”, a następnie odnaleźć pod tą „drugą intencją” kolejną „drugą intencję”, jak gdyby „trzecią"18. Na przykład, w „intencji rodzaju” (intentio generis), która zostaje przyporządkowana pojęciu „zwierzę w ogóle”, można odnaleźć w ujęciu poznawczym „drugą intencję”, ,intencję gatunku” (intentio species), a następnie kolejne intencje „definicji”, „predykatu”, „sądu”, „relację poprzednika”, „następnika”, „środka”, „skrajności” itd.; wszystkie one są intencjami denominowanymi w oparciu o czysto myślne operacje intelektu ${ }^{19}$. Przy czym ta pierwsza „intencja rodzaju” denominuje drugą, podlegającą jej „intencję gatunku”20. Mimo tych dystynkcji Suárez stwierdza, że wszystkie tego typu intencje określa się nie jako „intencje trzecie” czy „czwarte”, ale jako „drugie intencje” bądź „drugie ujęcia” czy „spostrzeżenia przedmiotowe” (secundae notiones obiectivae) ${ }^{21}$. Wynika to z faktu, iż wszystkie „intencje” odnoszą się do przedmiotu

inde participans aliquas proprietates..." (Disputationes metaphysicae, disp. LIV, sek. 6, art. 10). Zob. także art. 11.

${ }^{18}$ Disputationes metaphysicae, disp. LIV, sek. 6, art. 9. Refleksyjność intelektu nad samym sobą bądź duszy nad samą sobą rozważa również Ch. Wolff († 1754). Zob. B. Paź, Epistemologiczne założenia Christiana Wolffa, Wrocław 2002, s. 69-72 (Natura i podstawowe typy refleksji w ujęciu Wolffa).

19 „Unde iuxta triplicem operationem intellectus triplex etiam est ordo talium relationum, nam ex prima operatione consurgunt relationes generis, speciei, definitionis, definiti, etc.; ex secunda operatione, relatio praedicati, subiecti, copulae, propositionis; ex tertia, relatio antecedentis, consequentis, medii, extremitatis, etc. Hae namque relationes non conveniunt rebus secundum se, sed ut denominatis ab aliqua operatione intellectus, et ideo semper rationis sunt, et non reales" (Disputationes metaphysicae, disp. LIV, sek. 6, art. 9).

${ }^{20}$ „Hinc vero ulterius nascitur, ut possit intellectus supra ipsasmet secundas intentiones iterum reflecti, et convenientias, vel differentias inter ipsas considerare, et eas definire, vel ex eis discurrere, atque ita in eis similes relationes fundare; ut ex genere et specie abstrahit relationem universalis, et illud denominat genus, et sic de aliis" (Disputationes metaphysicae, disp. LIV, sek. 6, art. 11).

${ }^{21}$ „Quia ergo illae relationes logicales semper fundantur in huiusmodi cognitione reflexa, ideo peculiariter dicuntur secundae intentiones, seu secundae notiones obiectivae..." (Disputationes metaphysicae, disp. LIV, art. 10). 
jako przedmiotu poznawczego, a bycie bytem poznawczym przedmiotowym jest zawsze drugim porządkiem istnienia dla rzeczy w intelekcie, choćby liczba tych intencji była nieskończona ${ }^{22}$. Należy zaznaczyć, że „druga intencja” nie zakłada „pierwszej” jako czegoś korelatywnego i wyprowadzanego na mocy odniesienia terminologicznego, ale zakłada „pierwszą intencję" jako podmiot, którego jest atrybutem. Toteż zostaje ona wyrażona w odniesieniu do porządku „pierwszej intencji” jak gdyby w odniesieniu do podmiotu, nad którym jest nadbudowana, nie zaś tylko przez analogię terminów. „Relacja” jest wyrażona w podobny sposób, tzn. na sposób istnienia bytu jednostkowego, zakładając go jako swój podmiot i fundament bytowy, nie zakłada go natomiast jako korelacji terminu. Niemniej jednak racja istnienia „relacji” zawiera się w pojęciu, przez co staje się ona korelatem intencjonalnym. Podobnie formalna korelacja „drugiej intencji” jest zawsze jakąś drugą intencją, jak rodzaj do gatunku i vice versa. W odniesieniu do podziału „drugich intencji" Suárez stwierdza, że wszystkie intencje są podzielone na mocy odniesienia do ich najbliższego fundamentu (fundamenti proximi) lub racji ustanowienia (rationis fundandi). Skoro więc fundamentem bytowym „drugich intencji” jest byt poznawczy rzeczy ujętej w poznaniu, to „druga intencja” dzieli się również w zależności od określonego porządku poznania danego przedmiotu (diversum ordinem cogniti). Wynika to z faktu, że każda operacja intelektu ma swoje określone nakierowanie poznawcze, ujmuje określoną rzecz w jej odpowiednim statusie poznawczym i nacechowaniu.

Można powiedzieć, że „drugie intencje” stanowią ujęcie poznawcze rzeczy wyrażonej w poznaniu na sposób przedmiotowy. Między

22 „Relationes generis, speciei, et similes, cur nomen secundae intentionis usurparint. - Atque ob hanc causam solent hae ultimae relationes rationis peculariter appellari secundae intentiones, quasi resultantes ex secunda intentione seu attentione vel consideratione intellectus, quo nomine proprie vocatur intellectio reflexiva, quia supponit aliam circa quam versatur” (Disputationes metaphysicae, disp. LIV, art. 10); „Plura vero de his relationibus dicere, ad particulares scientias spectat, quia hae relationes in infinitum fere multiplicari possunt per fictiones vel reflexiones intellectus" (Disputationes metaphysicae, disp. LIV, art. 11). 
tymi rzeczami, bytami poznawczymi zachodzą jedynie stosunki myślne, a więc całkowicie nierealne. Jakkolwiek w ujęciu scholastycznym Suáreza jedynie ontologia bytu myślnego zdolna jest badać owe byty, konstrukcje mentalne, wprowadzając i określając zachodzące między nimi zależności i relacje na sposób myślny. Jedyne możliwe powiązanie ontyczne z bytem realnym odbywa się poprzez zapośredniczenie „drugiej intencji” w „pierwszej intencji”, która ma status realny. Stąd aby zdefiniować „byt przedmiotowy” w odniesieniu do „realności”, który jest bytem „drugiej intencji”, konieczne jest wykazanie, czy zachodzi jakikolwiek związek realnościowy między bytem „pierwszej intencji” a bytem „drugiej intencji”. Uzasadnienie tego związku jest równoznaczne z wykazaniem, że akt refleksji intelektu, który został nakierowany na przedmiot „drugich intencji”, odnosi się jednak do pojęć ogólnych, a więc wyabstrahowanych cech realnych bytu bądź realnych własności indywiduów. Suárez zatem wykazuje, że przedmiot poznawczy aktu „drugiej intencji”, ów byt przedmiotowy to treść pojęć formalnych, które odnoszą się do bytu realnego ${ }^{23}$. Abstrakcja "pierwszej intencji” odrywa cechy przedmiotów realnych, natomiast abstrakcja „drugiej intencji”, która odbywa się na poziomie przedmiotowym intelektu, dotyczy tylko pojęć abstrakcyjnych, w których pojęcie „realności” ma już charakter wyabstrahowany. Byt „drugich intencji” intelektu jest ujęciem poznawczym odzwierciedlającym wyabstrahowane natury rzeczy na sposób myślny, lecz nie wyłącznie czysto myślny (pure rationis). W tym wypadku przedmiotem „drugich intencji” jest obiekt intencjonalny, który reprezentuje w postaci „pojęcia formalnego” rzecz realną ${ }^{24}$, stąd pod pewnym względem „druga intencja” może zachowywać również charakter realny.

${ }^{23}$ „... dici possint aliquo modo fundari in operatione intellectus, ex qua consurgunt, quae operatio semper supponit alium conceptum entis realis" (Disputationes metaphysicae, disp. LIV). Zob. również disp. LIV, sek. 2, art. 16.

${ }^{24} \mathrm{O}$ relacji realnej między obrazem rzeczy w intelekcie (imago in intellectu) a „pojęciem formalnym" zob. Disputationes metaphysicae, disp. II, sek. 1, art. 11. 
Same zaś „drugie intencje”, które analizuje Suárez, powstają na skutek refleksyjnego poznania umysłu nad samym sobą, własnym poznaniem. Logika, jak chce np. Jan od św. Tomasza, nie jest nauką mogącą dokonać właściwej parcelacji bytów w obrębie intencji ${ }^{25}$, mimo iż ontologia bytu myślnego może wskazywać na istnienie nauki, której rozstrzygnięcia uwarunkowane są przez logiczną dialektykę intelektu. Byt „drugich intencji” - w odróżnieniu od Jana - jest dla Suáreza jednym z bytów wchodzących w szerszy podział metafizyczno-logicznej charakterystyki przedmiotów poznania. Stąd u Suáreza problematyka „pierwszych" i „drugich intencji” rozciąga się na całą metafizykę poznania.

\section{RELACJA MIĘDZY INTELEKTEM CZYNNYM A MOŻNOŚCIOWYM}

Dopiero tak zdefiniowany status poznania przedmiotowego umożliwia przejście do ścisłej teorii poznania intelektualnego i zdefiniowania adekwatnego przedmiotu metafizyki, którym niewątpliwie dla Suáreza jest uprzedmiotowione pojęcie „bytowości realnej” - jako ratio entis. Określenie "bytu przedmiotowego" nie stanowi tu jednak o naturze wszystkich bytów. Odnosi się jedynie do bytów, które - jako uprzedmiotowione - mogą mieć statusu istnienia przedmiotowego (esse obiectivum) na poziomie „drugiej intencji” intelektu, niemniej jednak poza intelektem (extra intellectum) są wewnętrznie niesprzeczne i zachowują zdolność do istnienia realnego ${ }^{26}$.

Pojęcie „formalne” jest więc płaszczyzną pierwszej instancji poznawczej, na której dochodzi do wyrażenia wyabstrahowanych z rzeczywistości ogólnych cech bytu. Ukazuje to stosunek rzeczywistości względem

${ }^{25}$ Ioannis a Sancto Thoma, Cursus Philosophicus Thomisticus, t. 1, Ars Logica, dz. cyt., 233a.

${ }^{26}$ „....interdum vero sumitur ut nomen significans de formali essentiam ejus rei quae habet vel potest habere esse, non ut exercitum actu, sed in potentiae vel aptidudine" (Disputationes metaphysicae, disp. II, sek. 4, art. 3); „....in prima ratione quidditatis realis intrat aptitude ad existendum, et in hoc primo distinguitur quidditatis realis a non reali seu ficta" (Disputationes metaphysicae, disp. III, sek. 2, art. 4). 
formalnej struktury intelektu. Z kolei pojęcie „przedmiotowe” wskazuje na relację między strukturą przedmiotową intelektu poznającego a bytem poznawczym (ens cognitum). Pojęcie „bytu przedmiotowego” jest ściśle związane z poznaniem intelektu, a jego związek z pojęciem „formalnym” jest oczywisty z punktu widzenia ludzkiej wiedzy (in mente efficimus ad concipiendum hominem) ${ }^{27}$. Podział ten wydaje się mieć szczególne znaczenie w wypadku kształtowania się ludzkiej wiedzy w trakcie odbywającego się poznania metafizycznego. Przede wszystkim w horyzoncie połączenia poznawczego między „przedmiotem poznania", który - inaczej niż w tradycji tomistycznej - u Suáreza może mieć strukturę zarówno realno-formalną, jak i czysto-przedmiotową, a „władzą poznającą”, której status w poznaniu intelektualnym jest całkowicie niematerialny.

Aby odczytać formułę programową i specyfikę „poznania przedmiotowego" w metafizyce Suáreza, a następnie uchwycić ewolucję poglądową w stosunku do św. Tomasza i tradycji filozoficznej, nieodzowna jest znajomość tomistycznej teorii poznania. Teoria „bytu” u Suáreza wydaje się sugerować potrzebę stosowania tego kontekstu. Otóż analiza „władz poznawczych” oraz ich „aktów” dowodzi, że przedmiot poznania jest wprost proporcjonalny w aspekcie poznawczym do „władzy poznającej”28. Takie założenie wyjściowe przyjmuje również Suárez,

${ }^{27}$ "Conceptus obiectivus dicitur res illa, vel ratio, quae proprie et immediate per conceptum formalem cognoscitur seu repraesentatur; ut, verbi gratia, cum hominem concipimus, ille actus, quem in mente efficimus ad concipiendum hominem, vocatur conceptus formalis; homo autem cognitus et repraesentatus illo actu dicitur conceptus obiectivus, conceptus quidem per denominationem extrinsecam a conceptu formali, per quem obiectum eius concipi dicitur" (Disputationes metaphysicae, disp. II, sek. 1, art. 1); „Priori modo dicimus essentiam realem esse, quae in esse nullam involvat repugnatiam..." (Disputationes metaphysicae, disp. II, sek. 4, art. 7).

${ }^{28}$ Por. Św. Tomasz z Akwinu, Traktat o człowieku. Summa teologii I, 75-89, przeł. S. Swieżawski, Kęty 1998, q. 85, art. 1 c, s. 544. Więcej na temat tomistycznej struktury poznania intelektualnego rzeczy materialnych zob. q. 85-86, s. 523-614. To założenie poznawcze było w filozofii przekonaniem powszechnym, sięgającym aż do teorii „odbicia" Platona († 347 p.n.e.). Por. Platon, Timaios, przeł. W. Witwicki, Kęty 2002, 45B-46C; Platon, Sofista, przeł. W. Witwicki, Kęty 2002, 266C. 
chociaż zasadniczo różni się od koncepcji tomistycznej, ponieważ w połączeniu, do jakiego dochodzi między intelektem a rzeczą, przyznaje większą rolę aktywności wytwórczej intelektu i jego emanacjom poznawczym, aniżeli bierno-receptywną w stosunku do rzeczy poznawanej ${ }^{29}$.

Każda „władza poznawcza” zdolna jest do aktu poznania wtedy, kiedy „połączy” się z przedmiotem poznawanym. W przypadku intelektu, który jest władzą całkowicie niematerialną, można założyć, że wchodzi on w poznaniu w kontakt z przedmiotem niematerialnym. Mówi się wówczas, że intelekt ujmuje w poznaniu formę intelektualno-poznawczą, "obraz inteligibilny wrażony” (species intelligibilis impressa) danego przedmiotu poznania. „Obraz inteligibilny” nie stanowi kompleksu jakości zmysłowych, zwanych przypadłościami, ale ujmuje konstrukcję treściową samej rzeczy, którą jest zespół relacji cech istotnościowych danego bytu. Po przyjęciu „formy intelektualnej”, która jest nazywana również „zastępczą”, akt intelektu modyfikuje się i ujawnia „pojęcie wyrażone" (species intelligibilis expressa), za pośrednictwem którego pojawia się "sąd”. Akt intelektualnego poznania jest zatem - jak napisze Jan od św. Tomasza - „actio metaphysica pura respiciens obiectum consideratione attactum” ( czynnością czysto metafizyczną, mającą na uwadze przedmiot ujęty myśleniem") ${ }^{30}$. Zgodnie z tradycją tomistyczną dematerializacji przedmiotu i przekształcenia go w formę intelektualno-poznawczą dokonuje tzw. „intelekt czynny” (intellectus agens), natomiast władzą, która w ujęciu poznawczym rozważa formy intelektualne, jest tzw. „intelekt możnościowy” (intellectus possibilis) ${ }^{31}$. „Intelekt czynny" zatem odpowiada za dematerializację przedmiotu i tak wyabstrahowany przedmiot przekazuje do „intelektu możnościowego”, intelek-

${ }^{29}$,...veritatem realem consistere in adaequatione quadam seu conformitate inter rem et intellectum..." (Disputationes metaphysicae, disp. VIII, prol.).

${ }^{30}$ Por. M. A. Krąpiec OP, Z teorii i metodologii metafizyki, w: Dzieła, t. 4, Lublin 1994, s. 72-76.

31 Zob. Św. Tomasz z Akwinu, Kwestie dyskutowane o prawdzie, t. 1, przeł. A. Aduszkiewicz, L. Kuczyński, J. Ruszczyński, Kęty 1998, q. I, art. 2, s. 21-22, q. X, art. 6, s. 453459. Zob. również J. Owens, Judgment and Truth in Aquinas, "Mediaeval Studies” (1970) 32, s. $138-158$. 
tu poznającego, który poznaje przedmiot ogólnie przez pryzmat istoty. Zdolność intelektu nie jest jednak ograniczona wyłącznie do poznawania istot rzeczy zmysłowych, może on również poznawać przedmiot w intelekcie, który nie będąc bytem realnym, jest ujmowany przez intelekt na sposób bytu (per modum entis). Ten przedmiot nazywany jest przez Suáreza bytem myślnym.

Powyżej zarysowany schemat arystotelesowsko-tomistycznego poznania intelektualnego był powszechnie akceptowany przez tradycję scholastyczną. Tomaszowa formuła „cognita sunt in cognoscente secundum modum cognoscentis” („rzecz poznawana znajduje się w poznającym zgodnie ze sposobem poznawania"32) odzwierciedla podstawowe założenie średniowiecznej teorii poznania, zgodnie z którą we władzy poznającego wyraźnie dochodzi do modyfikacji przedmiotu poznawczego. Suárez pogłębia tę teorię poprzez wprowadzenie teorii „bytu przedmiotowego”, ściśle związanej z ontologią bytu realnego i myślnego w metafizyce.

Relacja zależności poznawczej między „przedmiotem” a „podmiotem”, do której wyrażenia dochodzi w opisanym przez Suáreza stosunku (rzeczywistość)-(pojęcie formalne)-(pojęcie przedmiotowe)-(intelekt możnościowy), określa strukturę ludzkiego poznania w porządku metafizycznym, w którym poznanie odbywa się na poziomie przedmiotowym intelektu. Suárez zmienia jednak schemat poznania intelektualnego, które w średniowiecznej teorii za punkt wyjścia przyjmuje „zmysłowość, egzystencję, byt realny z jego nacechowaniem akcydentalnym. Byt ten następnie zostaje zdematerializowany przez „intelekt czynny” i przekształcony w „formę intelektualno-poznawczą"33. W tradycyjnym ujęciu mamy więc do czynienia z relacją poznawczą (rzeczywistość)-(forma intelektualna)-(intelekt możnościowy). Suárez niewątpliwie ma na uwa-

${ }^{32}$ Sancti Thomae de Aquino, Summa Theologiae II ${ }^{a}-I I^{a e}$, Textus Leoninus, Romae 1895, q. 1, a. 2. Zob. również Św. Tomasz z Akwinu, Traktat o człowieku. Summa teologii I, 75-89, dz. cyt., q. 76, art. 1, 3, s. 86.

${ }^{33}$ Św. Tomasz z Akwinu, Traktat o człowieku. Summa teologii I, 75-89, dz. cyt., q. 10, art. 6, s. $455-456$. 
dze nową postać definicji poznania intelektualnego, w które wprowadza dodatkową płaszczyznę „przedmiotową” na oznaczenie czystej aktywności intelektu poznającego. Zdaje się jednocześnie informować, że jest to płaszczyzna, w której rozstrzyga się poznanie metafizyczne i w istotny sposób warunkuje aktywność „intelektu możnościowego" ${ }^{\text {"4 }}$.

Natomiast w tomistycznym rozumieniu wiedzy człowiek nie może niczego poznać z głębi czystego intelektu. Jeśli nie jest on zapośredniczony o rzeczy zmysłowe, materialne, aktualne w zmysłowości, choć niezaktualizowane intelektualnie, intelekt nie zdołałby utworzyć „formy intelektualno-poznawczej", odwołując się jedynie do refleksyjnego poznania. Percepcja zmysłowa jest zatem w tradycji arystotelesowsko-tomistycznej miejscem (locus) i bezpośrednią sferą danych (data), w obrębie której rozgrywa się ludzkie poznanie intelektualne. Jest ono oparte na percepcji obserwacyjnej. Nieodwołanie się do sfery empirycznej uniemożliwiałoby dojście intelektu do poznania pewnej prawdy o bycie, do prawdy w nauce. Tym samym poznanie pierwszych zasad bytu (prima principia), które są również zasadami rozumowania teoretycznego, nie byłoby możliwe bez odwołania się do sfery zmysłów. Bez podstawy osadzonej w doświadczeniu aprioryczno-wytwórcza zdolność intelektu nie mogłaby mieć przedmiotu poznania. Tak więc w początkowej fazie metafizycznego poznania zachodzi dla tomistów konieczność wyjścia poza - można powiedzieć - formalny racjonalizm (przeciwnie u Kanta) i odwołania się do bazy zmysłów. Stanowi ona fundament wszelkich asercji i uogólniania. Odzwierciedla to zasadniczą dla poznania rzeczywistości relację, jaka zachodzi między rozumem a zmysłami.

Jest ze wszech miar rzeczą oczywistą, że siłą sprawczą, która odpowiada za poznanie intelektualne $\mathrm{w}$ tradycji arystotelesowsko-tomistycznej, jest akt immanentny władz poznawczych duszy ${ }^{35}$. A więc

${ }^{34}$ Zob. Francisco Suárez SJ, Commentaria una cum quaestionibus in libros Aristotelis De Anima, Introducción y edición crítica por Salvador Castellote, t. 3, Madrid 1991, disp. VIII-IX.

${ }^{35} \mathrm{Na}$ temat władz duszy zob. Św. Tomasz z Akwinu, Traktat o człowieku. Summa teologii I, 75-89, dz. cyt., q. 76, art. 1, 3-4, s. 86; q. 76, art. 3 C, s. 110; q. 76, art. 8, 4, ad 4, 
na pewno działanie „intelektu czynnego” i „możnościowego”. Nie są to akty transcendentne, a więc zmysłowe. W wypadku wszystkich aktów transcendentnych podmiot w poznaniu jest nakierowany na coś, co istnieje niezależnie od ujęcia poznawczego albo co najmniej ów akt poznawczy zewnętrzny odnosi się w poznaniu do bytu realnego, któremu przysługują atrybuty materialne.

W wypadku aktów immanentnych, pośród nich wyróżnia się: 1) „władze poznawcze” (potentiae cognoscitivae) i 2) "pożądawcze” (potentiae appetitivae $)^{36}$. Przedmiot poznawany przez „zmysły zewnętrzne”, które wchodzą w zakres działania „władz poznawczych”, to jakości dotykowe, węchowe, słuchowe, smakowe, nieharmonijne dźwięki, jednym słowem niezespolone jakości zmysłowe. Czynnikiem, który przyczynia się do prawidłowości poznawczej, obok „zmysłów zewnętrznych” (sensus externus), jest zespół władz zmysłowych, które nazywamy „zmysłami wewnętrznymi" (sensus internus). Suárez zachowuje wierność tradycji tomistycznej, zgodnie z którą w skład władz poznawczych zmysłowych wchodzą 1) „zmysły zewnętrzne” (dotyk - tactus, smak - gustus, węch olfactus, słuch - auditus, wzrok - visus) i 2) „zmysły wewnętrzne” (zmysł wspólny - sensus communis, wyobraźnia - imaginativa, władza oceny

s. 146 ; q. 77 , art. 1, s. 149-163, 163, 167, 170; q. 77, art. 2, s. 178; q. 77, art. 3, s. 181; q. 77, art. 6, s. 194; q. 78, art. 4, ad 3, s. 254; podział władz: q. 77, art. 4, s. 163, 167, 187, 188; władze umysłowe: q. 75, art. 2 c, s. 30; q. 75, art. 5 c, s. 42; q. 76, art. 1, 4, s. 86; q. 76, art. 1, ad 1, s. 95; q. 77, art. 1, 1, ad 1, s. 174; q. 77, art. 4 c, s. 188; q. 77, art. 8 c, s. 204; władze zmysłowe: q. 75 , art. 5 c, s. 43; q. 76, art. 2 c, s. 102; q. 77, art. 4 c, s. 188; q. 77, art. 8, 3, ad 3, s. 202; q. 77, art. 8 c, s. 204; władze wegetatywne: q. 78, art. 2, s. 214, 236.

${ }^{36} \mathrm{~W}$ sprawie podziału władz poznawczych u F. Suáreza zob. F. Suárez, De anima, w: Opera Omnia, Editio nova, a C. Berton, t. 3, Parisiis 1851, ks. III, c. 30; ks. II, c. 6, q. 2 [dalej: De anima]. Zob. zwłaszcza F. Suárez, Commentaria una cum quaestionibus inlibros Aristotelis De Anima, Introducción y edición crítica por Salvador Castellote, t. 3, Madrid: Fundación Xavier Zubiri 1991 [dalej: Commentaria una cum quaestionibus inlibros Aristotelis De Anima], disp. VIII (De sensibus interioribus); disp. IX (De potentia intellectiva); disp. X (De appetitivis potentiis in communi); disp. XI (De appetitu sensitivo); disp. XII (De appetitu rationale seu de voluntate); disp. XIII (De potentia motiva secundum locum); disp. XIV (De anima separata). 
zmysłowej - vis aestimativa, pamięć - memoria ${ }^{37}$ ). Na poziomie poznania zmysłowego nie wyczerpuje się poznanie człowieka. Człowiek wznosi się ponad proste dane zmysłowe dzięki najwyższej władzy poznawczej duszy, jaką jest intelekt (intellectus). Ponadto istnieje jeszcze władza, za pomocą której człowiek wnioskuje. Nazywamy ją „rozumem szczegółowym” lub „władzą osądu umysłowego” (vis cogitativa). W przeciwieństwie do człowieka zwierzęta posługują się bezpośrednio tylko „władzą osądu zmysłowego" (vis aestimativa), która pozwala im na natychmiastową reakcję na bodziec (w chwili zagrożenia). Od tej ostatniej zależy czwarta władza zmysłowa, jaką jest "pamięć” ${ }^{38}$.

Należy podkreślić szczególną rolę poznawczą „wyobraźni” (imaginativa), występującej także pod pojęciem "fantazji” (phantasia) ${ }^{39}$. Jest ona ważną władzą w porządku poznania intelektualnego również dla Suáreza $^{40}$. W ujęciu tomistycznym ta władza poznawcza, która nazywa się „zmysłem wspólnym”, przyjmuje formy poznawcze przedmiotów zmysłowych, natomiast ta, która nazywa się „wyobraźnią", odpowiada za przechowywanie form poznawczych. Są to jednak podobizny rzeczy

${ }^{37}$ Na temat „pamięci” zob. Commentaria una cum quaestionibus in libros Aristotelis De Anima, disp. IX, q. 10 (Utrum in parte intellectiva sit memoria vel aliqua potentia cognoscitiva ab intellectu distincta).

${ }^{38}$ Por. E. Gilson, Tomizm, przeł. J. Rybałt, Warszawa 1998, s. 239-240. W sprawie phantasia zob. Sancti Thomae Aquinatis, In III de Anima, lect. V, ed. A. M. Pirotta, Torino 1959, s. 216-223 (podaję za E. Gilson, Tomizm, dz. cyt., s. 240). W sprawie zmysłowych władz poznawczych „zewnętrznych” i „wewnętrznych” u Jana od św. Tomasza (oponenta F. Suáreza) zob. R. Waszkinel, Przedmiot i podmiot w poznaniu wedtug Jana od św. Tomasza, „Roczniki Filozoficzne” (1976) 24, z. 1, s. 31-45. Zob. również studium nad sferą poznania „zewnętrznego” i „wewnętrznego” w ujęciu tomistycznym Jana z Głogowa: Z. Kuksewicz, Jan z Głogowa. Koncepcja duszy, „Studia Mediewistyczne” (1964) 6, s. 137-246, zwł. 141-169.

${ }^{39} \mathrm{Na}$ temat władzy „wyobraźni” zob. św. Tomasz z Akwinu, Traktat o człowieku. Summa teologii I, 75-89, dz. cyt., q. 76, art. 2, 4, s. 99; q. 77, art. 8, 6, s. 203; q. 78, art. 4, S. 224, 252, 254, 256; q. 84, art. 6, ad 2, s. 511.

${ }^{40}$ De anima, ks. IV, art. 2. 4; Commentaria una cum quaestionibus in libros Aristotelis De Anima, disp. IX, q. 7 (Utrum intellectus noster pendeat in cognitione sua, pro hoc statu, a cognitione phantasiae). 
w wyobraźni odnoszące się do istnienia rzeczy materialnych. Intelekt, będąc władzą duchową, nie jest władny wyprowadzić poznania $\mathrm{z}$ „formy materialnej", albowiem nadal pozostaje ona formą indywidualnej rzeczy odnoszącej się do sfery zmysłowej bytu ${ }^{41}$. Konieczne jest zatem zdematerializowanie „formy materialnej” i przekształcenie jej w czystą „formę intelektualno-poznawczą", której struktura odzwierciedlałaby w sposób ogólny istotnościowe relacje zawierające się w rzeczy. Konieczność ta podyktowana jest naturą samego intelektu, który poznaje byt (rzeczy jednostkowe) nie w sposób bezpośredni i konkretny, ale aspektywnie i ogólnie. Stąd „forma poznawcza” jest tym „tworem” intelektu, poprzez który intelekt poznaje świat rzeczy zmysłowych ${ }^{42}$. Relacja, jaka zachodzi w połączeniu poznawczym między „formą intelektualno-poznawczą” a „intelektem możnościowym”, jest identyczna ze stosunkiem zarówno aktu będącego w relacji do możności, jak i formy aktualizującej materię, doskonałości będącej w stosunku formy wobec tego, co doskonalone ${ }^{43}$.

W zaprezentowanej koncepcji arystotelesowsko-tomistycznego poznania intelektualnego jedynie dzięki pośrednictwu „formy intelektualnej" możliwe jest poznanie ludzkie. W ujęciu tomistycznym zachodzi jednak pewna nieścisłość. Mianowicie Suárez, kwestionując zasadność teorii tomistycznej, wskazuje, że „forma poznawcza” (species intelligibilis), którą „intelekt czynny” tworzy z „wyobrażenia” (phantasia) i następnie przekazuje do „intelektu możnościowego”, spełnia funkcję obrazu w intelekcie (imago in intellectu), w którym w dalszym ciągu zostaje zachowana korelacja z formą materialną rzeczy zmysłowej ${ }^{44}$. Stąd - jak

${ }^{41}$ Św. Tomasz z Akwinu, Traktat o człowieku. Summa teologii I, 75-89, dz. cyt., q. 79, art. 3, ad 4, S. 291.

${ }^{42}$ Św. Tomasz z Akwinu, Traktat o człowieku. Summa teologii I, 75-89, dz. cyt., q. 85, art. 2, S. $552-559$.

${ }^{43}$ Św. Tomasz z Akwinu, Traktat o człowieku. Summa teologii I, 75-89, dz. cyt., q. 79, art. 3, zwłaszcza ad. 3, s. 290-294.

44 „Et haec est mens D Thomae, supra, et Aristotelis, hic tx 10, ubi ait quod intellectus noster percipit quidditates sensibilium; et cap 7 et 8, ubi ait intelligibilia a nobis esse quae repraesentantur in phantasmatibus" (Commentaria una cum quaestionibus in libros Aristotelis De Anima, disp. VIII, q. 4, art. 5). 
wyjaśnia Suárez - jej poznanie przez „intelekt możnościowy” (intellctus agens) wydaje się niemożliwe, albowiem jest on władzą duszy całkowicie niematerialną, pomimo iż wszystkie te władze istnieją w tej samej duszy, która jest formą ciała (in una eademque anima) ${ }^{45}$. Wyobraźnia, która przechowuje formy odnoszące się do materii zmysłowej, jest władzą niedoskonałą (phantasma est imperfectior) ${ }^{46}$. Wyobraźnia zawiera jedynie formy rzeczy pojedynczych, stąd intelekt, który poznaje rzeczy jednostkowe za pośrednictwem pojęć ogólnych, nie jest determinowany przez strukturę poznania wyobraźni ${ }^{47}$. Jedynie anioły mają bezpośrednie formy bytów jednostkowych ${ }^{48}$. Natomiast intelekt człowieka pozna-

45 „Intellectus noster est spiritualis; ergo res materialis non potest esse illi proportionata. Respondetur: Est quidem spiritualis,tamen potentia animae, quae est forma corporis, et ideo ex parte corporis habet quod tantum corporalia, ut proportionata sibi, intelligat; ex parte vero suae spiritualitatis habet quod illa intelligat spirituali modo" (Commentaria una cum quaestionibus in libros Aristotelis De Anima, disp. VIII, q. 4, art. 6). Więcej zob. disp. IX, q. 8 (Quid sint intellectus agens et possibilis).

${ }^{46}$ Commentaria una cum quaestionibus in libros Aristotelis De Anima, disp. IX, q. 2, art. 8).

47 „Prima conclusio sit: Intellectus agens numquam efficit species nisi a phantasiae cognitione determinetur. Haec conclusio patet ex dictis et experientia. Ratio autem esse potest, nam intellectus agens est indifferens ad efficiendas omnes species, et ideo, ut efficiat has vel illas indiget aliquo determinante; nihil est autem aliud a quo possit determinari nisi a phantasiae cognitione" (Commentaria una cum quaestionibus in libros Aristotelis De Anima, disp. IX, q. 2, art. 11); „Item, repraesentatio phantasmatis semper manet materialis; ergo semper est rei singularis" (Commentaria una cum quaestionibus in libros Aristotelis De Anima, disp. IX, q. 2, art. 6); „Secunda conclusio: Intellectus noster cognoscit singulare materiale per propriam speciem illius. Haec probatur duplici medio: Primum est, quia nihil repugnat dari speciem impressam repraesentativam rei singularis ut sic; ergo talis species potest fieri ab intellectu agente; in possibili ergo cognoscitur singulare per propriam speciem. Antecedens probatur: $1^{\circ}$, Nam potest dari species expressa et proprius conceptus rei singularis, ut probatum est; ergo et species impressa et propria, ex dictis supra, d 5, q 5, circa difficultatem quintam" (Commentaria una cum quaestionibus in libros Aristotelis De Anima, dis. IX, q. 3, art. 5).

${ }^{48}, \ldots$...probatur idem antecedens, nam in angelis dantur species spirituales repraesentantes propria singularia materialia ut sic; [...] res materialis individua potest etiam repraesentari spirituali modo ex parte speciei repraesentantis, ut in angelis pa- 
je poprzez pojęcia ogólne, podczas gdy intelekt anioła jest władzą poznania doskonalszego (perfecta cognitio); jest zdolny do bezpośredniego wyodrębnienia istoty rzeczy z wszystkich jej właściwości ${ }^{49}$. Wyobraźnia zatem nie poznaje w sposób ogólny cech wspólnych, ale zawsze poprzez odniesienie do rzeczy zmysłowej extra intellectum ${ }^{50}$. Sama z siebie nie może dokonać wewnętrznej modyfikacji, stąd nie może utworzyć właściwej formy intelektualno-poznawczej, która jest wszakże niezbędnym medium poznawczym intelektu jako władzy całkowicie duchowej (spiritualis tantum $)^{51}$. Wyobraźnia i intelekt nie zbiegają się w tworzeniu identycznej formy poznawczej. Potrzebne jest zatem, aby dusza wyemanowała pojęcie „pośrednie”, które jest pojęciem wyższego rzędu niż pojęcie materialne ${ }^{52}$. Dusza musi utworzyć pojęcie adekwatne względem władzy poznającej (formando conceptum adaequatum illius). Suárez stwierdza,

tet" (Commentaria una cum quaestionibus in libros Aristotelis De Anima, disp. IX, q. 3, art. 5).

49 "Sed est, $2^{\circ}$, advertendum quod perfecta cognitio quaedam est comprehensiva, quae est quando tota quidditas distinctissime et per eam omnes proprietates eius cognoscuntur. Sed hic modus cognitionis non est humanus, sed angelicus, nam humano modo tunc dicitur res perfecte cognosci, quando eius essentia proprio conceptu concipitur, et per illam cognoscuntur passiones propriae et non tantum communes. (46) Qui modus cognitionis perfectae haberi potest per speciem rei vel per effectum proprium rei, qui a sola illa fieri potest imperfecte autem cognoscitur res quando solum cognoscitur per communia" (Commentaria una cum quaestionibus in libros Aristotelis De Anima, disp. IX, q. 5, art. 3).

${ }^{50}$ „Item, repraesentare universale abstractum est repraesentare rationem communem non repraesentando individuas conditiones; est autem impossibile quod phantasma non repraesentet conditiones individuas; ergo. Item, si phantasma ipsum repraesentaret universaliter phantasia ipsa posset etiam universalia cognoscere. Consequens est falsum" (Commentaria una cum quaestionibus in libros Aristotelis De Anima, disp. IX, q. 5, art. 3).

${ }^{51}$ „Ex eo etiam constat falsum esse tertium dictum, nam phantasma semper manet materiale et in se immutatum; ergo non potest producere speciem intelligibilem se ipso perfectiorem" (Commentaria una cum quaestionibus in libros Aristotelis De Anima, disp. IX, q. 5, art. 3).

${ }^{52}$ „Et confirmatur, nam multo difficilius est quod anima efficiat rem spiritualem, mediante materiali, quam quod efficiat illam mediante sola virtute spirituali”; ,....ma- 
że „intelekt” jest władzą wyższą niż „wyobraźnia” i „zmysły”; jest zdolny do poznania istoty rzeczy ${ }^{53}$. Niemniej jest władzą pośrednią między intelektem aniołów, zawierającym formy (species) wszystkich rzeczy (ze względu na ich naturę i niezawodność) a władzą zmysłów, która - podobnie jak intelekt człowieka - nie zawiera żadnych form ${ }^{54}$. Stąd poznanie intelektualne jest procesem złożonym, w którym intelekt człowieka musi opierać się na danych wyobrażeniowych. Charakterystyczna dla ludzkiego intelektu jest postawa wyjściowa poznania.

Sama czynność poznania intelektualnego jest rozłożona przez Suáreza na trzy etapy ${ }^{55}$. W pierwszej relacji poznawczej (formalnej) intelekt „oświeca” wyobraźnię, odwołuje się do form zmysłowych przechowywanych w „wyobraźni”, która za pośrednictwem zmysłów czerpie

xime tam superioris quantum est res spiritualis supra materialem" (Commentaria una cum quaestionibus in libros Aristotelis De Anima, disp. IX, q. 2, art. 8).

${ }^{53}$ „Unde verum dicit ordinem ad intellectum, bonum ad voluntatem, intellectus autem est prior potentia quam voluntas. Quod si quis velit has passiones in perfectione etiam comparare et interroget quaenam illarum perfectior sit, potest imprimis facile responderi, de formali et secundum id quod addunt supra ens" (Disputationes metaphysicae, disp. III, sek. 2, art. 9).

54 „Intellectus noster quasi medius est inter intellectum angelicum et sensum..." (De anima, ks. IV, art. 8. 13); „Quomodo differant intellectus angeli et hominis. Sed petit argumentum, quomodo differant istae potentiae. Dicunt quidam quod istae potentiae, ut potentiae sunt, non differunt specie, tamen ut proprietates sunt a diversis essentiis, dimanantibus, differunt. Quae distinctio tradi solet de sensibus hominis et brutorum"; „De intellectu ergo angelico et humano Scotus, in 2, d 1, q. ultima, videtur dicere esse eiusdem speciei. Sed id non est credibile, ut patet ex diverso modo intelligendi unius et alterius. Et ideo dico differre specie, propter diversum modum attingendi obiectum, quia angelus attingit perfecte et simplici intuitu, alius imperfecte et cum discursu. Item, differunt ex parte obiecti proportionati, nam intellectus angelicus habet rem spiritualem et praecipue propriam essentiam ut proportionatum obiectum, noster vero habet rem materialem" (Commentaria una cum quaestionibus in libros Aristotelis De Anima, disp. VIII, disp. 4, art. 8).

55 „Nota quod intellectui agenti triplex solet tribui operatio: Prima, illuminatio phantasmatis; secunda, facere res actu intelligibiles; tertia, abstrahere a phantasmatibus. Quarta etiam solet tribui, quae est illustrare prima principia" (Commentaria una cum quaestionibus in libros Aristotelis De Anima, disp. VIII, q. 2, art. 16). 
je z rzeczy zewnętrznych (extrinsecis obiectis), stanowiących najbardziej elementarną podstawę poznania ${ }^{56}$. Wyobraźnia w pewnym stopniu współuczestniczy w tworzeniu formy poznawczej, ale jedynie jako czynnik wystarczający do poruszenia intelektu czynnego (sufficiens ad movendum intellectum $)^{57}$. Natomiast kolejny proces sprowadza się do abstrahowania od formy materialnej wyobraźni ${ }^{58}$. Z kolei ostatni etap polega na twórczej czynności intelektu na drugim poziomie abstrakcji, który chce utworzyć formę oczyszczoną ze zmysłowości, który wcześniej natrafia na istnienie reprezentacji poznawczej pod postacią formy zmysłowej, powstałej w wyniku poprzedzającego procesu abstrakcji formalnej ${ }^{59}$. Jakkolwiek intelekt nie zdobywa poznania wyłącznie na podstawie uprzedniego poznania form pochodzących z „wyobraźni", która przechowuje formy rzeczy zmysłowych, powstające w wyniku aktu intencji formalnej. „Intelekt czynny”, by mógł przekazać całkowicie niematerialną formę poznawczą do „intelektu możnościowego”,

56 „...potentiae autem sensitivae maxime exteriores speciebus carent, et illas ab extrinsecis obiectis recipiunt, intellectus vero noster, et declinat, et quandam habet convenientiam cum illo,... anima ipsa quippiam cognoscit per phantasiam, ab ipso intellectu manat species id repraesentans" (Commentaria una cum quaestionibus in libros Aristotelis De Anima, disp. VIII, q. 2, art. 16).

${ }^{57}$ Commentaria una cum quaestionibus in libros Aristotelis De Anima, disp. VIII, q. 2 , art. 16 .

58 „...intellectiva est in potentia ad similitudines rerum, non eo modo quo sunt in phantasmate, sed secundum quod elevantur ad aliquid altius, id est secundum quod abstrahuntur”; „Dicitur ergo quod species abstrahi, quia intellectus agens virtute sua efficit quamdam speciem spiritualem repraesentantem eamdem naturam quam phantasma repraesentat, non tamen materialiter, sicut phantasma representat, sed quoddam spirituali modo; et illa elevatio a materiali repraesentatione phantasmatis ad spiritualem repraesentationem intelligibilis speciei dicitur abstractio" (Commentaria una cum quaestionibus in libros Aristotelis De Anima, disp. VIII, q. 2, art. 17).

59 „De tertia tandem operatione, id est, abstractione est notandum quod species non dicitur abstrahi a phantasmatibus propterea quod ipsa species sit prius immixta phantasmatibus et postea ab intellectu agente separetur et collocetur in intellectu possibili. Hoc enim non est intelligibile, nam spirituale quomodo esset immixtum materiali" (Commentaria una cum quaestionibus in libros Aristotelis De Anima, disp. VIII, q. 2, art. 16); De anima, ks. IV, art. 4. 1. 
musi ją wyemanować z czystego intelektu w takiej postaci, w jakiej będzie ona łączyć wszystkie aspekty procesu poznania jednej i tej samej duszy, wszystkie elementy poznawcze władz duszy, zarówno odnoszące się do realności zmysłowej, jak i mające formę pojęcia czysto duchowego. Pochodną wszystkich związków i pojęć procesu poznania okazuje się dla Suáreza wyemanowane przez intelekt czysto poznawcze pojęcie „bytu przedmiotowego”, które umożliwia duszy wyświetlenie związków poznawczych na poziomie „intelektu możnościowego" ${ }^{60}$. Wszystkie wymienione relacje poznawcze poszczególnych władz mają status „bytu realnego", wszystkie bowiem są czymś realnym w duszy. Powoduje to, że pod względem "realności” - która stanowi tu podstawę wszelkiego bytu i poznania prawdziwego i która zostaje wyrażona w pojęciu „bytu przedmiotowego" (jako najogólniejsza cecha) - są one sobie równe ${ }^{61}$. Udział w „bycie” wszystkich władz poznawczych wraz z ich emanatami sprawia, że każdy z aspektów poznania może być ujęty w formie bytu przedmiotowego w jednej i tej samej duszy na poziomie „intelektu możnościowego" ${ }^{2}$. Każdy z tych aspektów jest wówczas „bytem po-

${ }^{60}$ Bliska temu stanowisku jest koncepcja „bytu przedmiotowego” nominalisty Gabriela Biela († 1495), którego Epitome była lekturą na uniwersytecie w Wittenberdze; czytał ją między innymi M. Luter († 1546). Por.: „Intellectus noster videns rem aliquam extra, fingit in se eius similitudinem, quae talis est in esse objectivo, qualis est res extra, quae fingitur, in esse subjectivo" (G. Biel, Epitome et Collectiorum ex Occamo circa quatuor Sententiarum Libros, Tübingen 1501 (reprint Frankfurt am Main 1965), I, d. 2, q. 4). W sprawie G. Biela zob. E. Gilson, Historia filozofii chrześcijańskiej w wiekach średnich, dz. cyt., s. 738-739.

${ }^{61}$ „Ultimo, ex re ipsa et quasi a priori probatur nostra sententia contra omnes praedictas, quia omnia entia realia vere habent aliquam similitudinem et convenientiam in ratione essendi; ergo possunt concipi et repraesentari sub ea praecisa ratione qua inter se conveniunt; ergo possunt sub ea ratione unum conceptum obiectivum constituere; ergo ille est conceptus obiectivus entis... ens habet aliquam convenientiam et similitudinem cum quolibet ente" (Disputationes metaphysicae, disp. II, sek. 2, art. 14).

${ }^{62}$ „Est enim advertendum phantasiam et intellectum hominis radicari in una anima; et hinc est quod in suis operibus habent ordinem et consonantiam; unde patebit, infra, quod eo ipso quod intellectus operatur, etiam imaginatio operatur. Ad hunc ergo modum arbitror intellectum possibilem de se esse nudum speciebus, habere tamen 
znawczym" (ens cognitum). Tym samym wszystkie procesy zachodzące w duszy tworzą w niej jeden strumień poznawczy. Natomiast cecha „przedmiotowości” jest właściwa wszystkim sklasyfikowanym bytom (również aktom duszy), albowiem każdy byt uprzedmiotowiony może w poznaniu mieć status „istnienia przedmiotowego” (esse obiectivum), nie przestając jednocześnie być „bytem realnym” (ens reale).

\section{PODSUMOWANIE}

W świetle powyższego ujawniają się zarówno różnorodność określeń dotyczących opisu poznania intelektualnego, jak również klasyczna koncepcja relacji między podmiotem a przedmiotem. Tradycyjna koncepcja tomistyczna nie wprowadza w obręb działania „władz” duszy pojęcia „bytu przedmiotowego”, podobnie jak nie występuje w niej sfera poznania czysto przedmiotowego. Dopiero Suárez „byt przedmiotowy” uczyni pojęciem „medialnym”, które uczestniczy w dematerializacji form. Stanowi pomost pomiędzy „formą zmysłowości”, którą przechowuje „wyobraźnia”, a „intelektem czynnym”, który następnie przekazuje w pełni niematerialną formę do „intelektu możnościowego”. Ten ostatni jest władzą całkowicie niematerialną. Stąd zachodzi konieczność wprowadzenia w relacji między „wyobraźnią” a „intelektem czynnym” takiej struktury poznawczej i takiego pojęcia, które pozwala na uniknięcie zróżnicowania między „formą materialną” wyobraźni a „władzą duchową” intelektu. Sama wyobraźnia nie jest wystarczającym medium, albowiem jest zdolna jedynie do reprezentowania form przedmiotów materialnych ${ }^{63}$. Stąd

animam virtutem spiritualem ad efficiendas species earum rerum, quas sensus cognoscit, in intellectu possibili" (Commentaria una cum quaestionibus in libros Aristotelis De Anima, disp. VIII, q. 2, art. 12).

63 „Et hinc oritur quaestio proposita. Nam intellectus non movetur, nisi ab obiecto in phantasmate repraesentato; phantasma autem materiale est; ergo non potest agere in intellectum spiritualem spirituales species" (Commentaria una cum quaestionibus in libros Aristotelis De Anima, disp. VIII, q. 2, art. 2); „... unde intellectus noster etiam ex se habet intelligere per species...obiectum proportionatum intellectui quod ab illo 
zostaje wprowadzone do systemu poznania pojęcie „bytu przedmiotowego”. Pojęcie „bytu przedmiotowego” charakteryzuje się właśnie taką postacią równoważności, dzięki której daje się wprowadzić w obszar działania władzy niematerialnej bardziej doskonałą „formę poznawczą”, oczyszczoną ze zmysłowości. Formę, która uwzględnia warunek istnienia przedmiotowego. „Intelekt” jest władzą duchową, władzą wyższego rzędu niż „wyobraźnia” (spiritualem potentiae superioris) ${ }^{64}$. Aczkolwiek „intelekt czynny” nie jest zdolny do wyemanowania „formy poznawczej” z całkowitym odrzuceniem działania „wyobraźni”, która przechowuje formy zmysłowe rzeczy ${ }^{65}$. Niemniej jednak nie jest on także w stanie wyemanować „formy duchowej” (spiritualis forma) z samej „wyobraźni materialnej" (nequit ex subiecto materiali) ${ }^{66}$. Suárez stwierdza zatem, że intelekt czynny nie może być całkowicie uwarunkowany przez wyobraźnię w tworzeniu formy poznawczej, lecz w jakiś sposób musi być zdolny do samodzielnej, duchowej aktywności ekspresyjno-twórczej ${ }^{67}$. W tym ujęciu władza wyobraźni spełnia jedynie rolę przyczyny sprawczej dla „intelektu czynnego" bądź przedmiotu występującego pod postacią materialnej formy wzorczej (materiam, et quasi exemplar intellectui agenti praebendo), w stronę której kieruje się „intelekt czynny”, aby na podstawie danej w wyobrażeniu formy materialnej wyemanować własną, całkowicie niematerialną ${ }^{68}$. „Wyobraźnia” zatem spełnia tu funkcję

per propriam speciem potest cognosci" (Commentaria una cum quaestionibus in libros Aristotelis De Anima, disp. VIII, q. 1, art. 5).

${ }^{64}$ De anima, ks. III, art. 1. 9.

65 „Intellectus agens numquam efficit specie, nisi a phantasiae cognitione determinetur..." (De anima, ks. IV, art. 2. 10).

${ }^{66}$ De anima, ks. IV, art. 2. 10.

${ }^{67}$ „Et ideo supra conclusimus intellectum indigere speciebus et similitudinibus rerum ad cognoscendum; quae species necessario debent esse spirituales, cum intellectus, qui eas recipit, spiritualis sit”; „animam ex natura sua esse similem omnibus rebus cognitis atque adeo sufficientem esse ad cognoscendas illas" (Commentaria una cum quaestionibus in libros Aristotelis De Anima, disp. VIII, q. 2, art. 1).

68 „Secunda conclusio: Haec determinatio non fit per efficientiam aliquam ipsius phantasmatis, sed per hoc solum quod materiam praebet et quasi exemplar intellectui agenti, idque propter unionem quam habet in eadem anima. Prima huius conclusionis 
na podobieństwo przykładowej formy wzorczej (ad istar exemplaris) ${ }^{69}$. "Intelekt czynny” tworzy „formę poznawczą” czysto przedmiotową za pośrednictwem czystego intelektu w duszy ${ }^{70}$. „Wyobraźni” można wówczas przypisać charakter akcydentalny, niezbędny do poruszenia „intelektu czynnego”, aczkolwiek „intelekt czynny” nie działa jedynie w obrębie działania „wyobraźni”71. Wyemanowaną „formę poznawczą” (species intelligibilis), całkowicie oczyszczoną z materialności, „intelekt czynny” przekazuje do „intelektu możnościowego” jako czyste pojęcie poznawcze (oczyszczone ze zmysłowości), a tym samym realizuje adekwatne poznanie intelektu aktualnie poznającego ${ }^{72}$. I zasadniczo w tym kontekście spełnia się dla Suáreza teoria poznania intelektualnego, a więc poprzez wstępną definicję struktury „drugiej intencji” aktów duszy, która jest strukturą przedmiotową intelektu, oraz przez wprowadzenie ścisłej definicji „bytu przedmiotowego”, który z kolei jest właściwą fo r mą reprezentacji poznawczej w poznaniu intelektualnym.

pars probatur ex dictis contra alias opiniones" (Commentaria una cum quaestionibus in libros Aristotelis De Anima, disp. VIII, q. 2, art. 12).

69 ,...ipsa imaginatione sensibili non concurrente effective ad eam actionem, sed habente se quasi materia, aut per modum excitantis animam, aut sane per modum exemplaris" (Commentaria una cum quaestionibus in libros Aristotelis De Anima, disp. VIII, q. 2, art. 12). Zob. także De anima, ks. IV, art. 2. 12.

${ }^{70}$ „Ad tertiam vero dicitur quod abstractio intellectus agentis non ita intelligitur ut sit productio speciei repraesentantis naturam communem abstractam a conditionibus individualibus, quas phantasma repraesentat, quamvis hoc modo soleat exponi, sed est ita intelligendum ut sit productio speciei spiritualis abstrahentis in suo esse a materialitate phantasmatis, ut supra exposuimus. Et haec de modo cognoscendi singularium"; „...quod species, per quam intellectus cognoscit singulare, debet esse spiritualis, cum quo stat quod sit repraesentativa rei singularis, ut ostensum est" (Commentaria una cum quaestionibus in libros Aristotelis De Anima, disp. IX, q. 3, art. 11).

${ }^{71}$,...phantasma nullam prorsus actionem habet intellectus agens, neque etiam phantasma active concurrit ad productionem speciei" (De anima, ks. IV, art. 2. 17).

${ }^{72}$ De anima, ks. IV, art. 2. 17. 


\section{THE THEORY OF INTELLECTUAL COGNITION (FRANCIS SUÁREZ' APPROACH)}

SUMMARY

This paper concerns Suárez intellectual cognition which is directly related to the theory of objective being, although understood differently than in the present times. In the discussion of intellectual cognition he placed the concept of first and second intention. Suárez especially indicates the order of so-called the "second intention" in which the intellect perceives being through the very objective being (noetic order), which is characterized by undivided and undifferentiated status at the level of active intellect. Thus Suárez' objective order of cognition is not distinctively determined. This makes the being to be comprehended through the objective concept of being from the noetic perspective as referring equally to the singular entities as well as universal, finite and infinite, being created and uncreated. Considering the above, one can agree with the position according to which Suárez' intellectual cognition can be considered as a scholastic theory that could have a significant bearing on the future epistemology in modern rationalism, especially which had considerable influence on the Cartesian model of subjective knowledge and Kantian critical transcendental philosophy. Suárez' approach meets with the theory that influenced the modern epistemology and post-Cartesian philosophy as a cognitive shift towards a new subjective prospect (e.g. in se conversa), in which reflection on real being was shifted toward the cognitive representations, that is, toward the noetic reflection and mentalism.

\section{KEYWORDS}

intelectual cognition, second intention, essence of being, passive and active intellect

BIBLIOGRAFIA

Ashworth E. J., The Tradition of Mediaeval Logic and Speculative Grammar, Toronto 1978. 
Aquinatis S. T., Scriptum super Sententiis magistri Petri Lombardi, t. 1, ed. P. Mandonnet, Parisiis 1929.

Aquinatis S. T., In Aristotelis librum de Anima commentarium (In III de Anima), ed. A. M. Pirotta, Torino 1959.

Aquino S. T. de, Summa Theologiae II ${ }^{a}$-IIae, Textus Leoninus, Romae 1895.

Biel G., Epitome et Collectiorum ex Occamo circa quatuor Sententiarum Libros, Tübingen 1501 (reprint Frankfurt am Main 1965).

Conti A. D., Second Intentions in the Late Middle Ages, w: Medieval Analysis in Language and Cognition, eds. S. Ebbesen, R. Friedmann, Copenhagen 1999, s. 453-470.

Darge R., Suárez' transzendentale Seinsauslegung und die Metaphysiktradition, Leiden-Boston 2004.

Doyle J. P., Prolegomena to a Study of Extrinsic Denomination in the work of Francis Suárez S. J., „Vivarium” (1984) 22, s. 121-16o.

Encyclopedia of Philosophy, ed. P. Edwards, t. 7, New York 1967.

Forlivesi M., La distinction entre concept formel et concept objectif: Suárez, Pasqualigo, Mastri, trad. di O. Boulnois, „Les Études Philosophiques” (2002) 1, S. 3-30.

Gilson E., Historia filozofii chrześcijańskiej w wiekach średnich, przeł. S. Zalewski, Warszawa 1987.

Gilson E., Tomizm, przeł. J. Rybałt, Warszawa 1998.

Grabmann M., Die Disputationes Metaphysicae des Franz Suárez in ihrer methodischen Eigenart und Fortwirkung, w: Mittekakterkuches Geustesleben. Abhandlungen zur Geschichte der Scholastik und Mystik, München 1926, S. 517-524.

Ioannis a Sancto Thoma, Cursus Philosophicus Thomisticus, t. 1, Ars Logica, Parisiis 1883.

Hellín J., El concepto formal en Suárez, „Pensamiento” (1962) 18, s. 407-432.

Krąpiec M. A., Z teorii i metodologii metafizyki, w: M. A. Krąpiec, Dzieła, t. 4, Lublin 1994.

Kretzman N., Semantics, History of, w: The Encyclopedia of Philosophy, ed. P. Edwards, New York 1967.

Kuksewicz Z., Jan z Głogowa. Koncepcja duszy, „Studia Mediewistyczne” (1964) 6, s. 137-246. 
Moody A. E., The Medieval Contribution to Logic, „Studium General” (1966) 19, S. $443-452$.

Moreno A. S., Logica Medieval, „Sapientia” (1961) 16, s. 246-265.

Ockham W., Suma logiczna, przeł. T. Włodarczyk, Warszawa 1971.

Ockham G. de, Scriptum in libros Sententiarum seu Ordinatio, w: G. de Ockham,

Opera philosophica et theologica, cura Instituti Franciscani, Universitatis

S. Bonaventurae, Opera theologica, t. 3, ed. Ph. Boehner OFM, G. Gál OFM,

S. Brown, New York 1977.

Ong W. J., Ramus, Method and the Decay of Dialogue: From the Art of Discourse to the Art of Reason, Chicago 2005.

Owens J., Judgment and Truth in Aquinas, "Mediaeval Studies” (1970) 32, S. $138-158$.

Paź B., Epistemologiczne założenia Christiana Wolffa, Wrocław 2002.

Pinborg J., Logic und Semantik im Mittelalter. Ein Überblick, Stuttgart 1972.

Platon, Timaios, przeł. W. Witwicki, Kęty 2002.

Platon, Sofista, przeł. W. Witwicki, Kęty 2002.

Scholz H., Zarys historii logiki, przeł. M. Kurecka-Wirpszowa, Warszawa 1965. Suárez F., De anima, w: Opera omnia, Editio nova, a C. Berton, t. 3, Parisiis 1851. Suárez F., Disputationes metaphysicae, w: Opera Omnia, Editio nova, a C. Berton, t. 25, Parisiis 1866.

Suárez F., Commentaria una cum quaestionibus in libros Aristotelis De Anima, Introducción y edición crítica por S. Castellote, t. 3, Madrid 1991.

Swieżawski S., Les intentions premières et les intentions secondaires chez Jean Duns Scotus, „Archives d'Histoire Doctrinale et Littéraire du Moyen Âge” (1934) 9, s. 205-26o.

Tomasz z Akwinu św., Traktat o człowieku. Summa teologii I, 75-89, przeł. S. Swieżawski, Kęty 1998.

Tomasz z Akwinu św., Kwestie dyskutowane o prawdzie, t. 1, przeł. A. Aduszkiewicz, L. Kuczyński, J. Ruszczyński, Kęty 1998.

Tomasz z Akwinu św., De veritate. O prawdzie, przekł. A. Białek, tekst poprawili M. A. Krąpiec OP, A. Maryniarczyk SDB, Lublin 1999.

Waszkinel R., Przedmiot $i$ podmiot w poznaniu wedtug Jana od św. Tomasza, „Roczniki Filozoficzne” (1976) 24, z. 1, S. 31-45. 
Wells N. J., „Esse cognitum” and Suárez Revisited, „American Catholic Philosophical Quarterly" (1993) 67, s. 339-348.

Wszystko to ze zdziwienia. Antologia tekstów filozoficznych XIV wieku, oprac.

E. Jung-Palczewska, Warszawa 2000.

Venetus P., Logica Parva, First Critical Edition from The Manuscripts with

Introduction and Commentary, transl. and ed. by A. R. Perreiah, LeidenBoston-Köln 2002 (Münich 1984). 